\title{
The Appropriateness of the Instrument in Assessing Children's Early Mathematical Abilities
}

\author{
Ni Wayan Intan Wahyuni ${ }^{1 *}$, Putu Aditya Antara ${ }^{1}$, Putu Rahayu Ujianti ${ }^{1}$ \\ ${ }^{1}$ Early Childhood Education Department, Faculty of Education, Universitas Pendidikan Ganesha, Indonesia \\ *Corrsponding author, Email: intanwahyuni935@gmail.com
}

\begin{abstract}
Lack of children's preliminary mathematics assessment skills causes the learning process in the classroom to be less optimal. This study aims to determine how the appropriateness of the instrument for assessing children's early mathematical abilities is seen from its validity and reliability. This type of research is development research (Research and Development) which is carried out using the RDR (Research, Development, Research) model. The subject of this study was an instrument for assessing the students' initial mathematical abilities which consisted of a grid and a questionnaire with a total of 14 items. The instrument for assessing students' initial mathematical abilities has been tested by two experts to measure the validity and reliability of the instrument. The results of the data analysis showed that: (1) 12 valid statements were made by calculating the validity of the student's initial mathematics ability assessment instrument of 0.75 with high validity criteria, and (2) the reliability of the student's initial mathematical ability assessment instrument was 0.80 with the criteria very high reliability. With the existence of an instrument for assessing children's early mathematical abilities, it can be used as a guide or reference for teachers in designing the learning process in the classroom, especially in mathematics learning.
\end{abstract}

Keywords: Early Childhood, Early Math Skills, Assessment Instrument

\section{INTRODUCTION}

One of important activities in the learning process of Early Childhood Education is enhancing the primary mathematical abilities of the early childhood. Munandar [1] stated that an ability is a potency to do something as the result of congenital and practice. According to Robin [2], an ability can be defined as a capacity of various tasks in a particular job. Therefore, an ability can be concluded as a potency of an individual as the result of congenital and practice that are conducted through any particular tasks. [3] stated that mathematics is a science of numbers, a correlation of numbers and operational procedure which is used to solve any cases in term of numbers. In line with Sujono [4] mathematics is considered as a knowledge about logical reasoning and a supporting knowledge in interpreting any ideas. As added by [5] mathematical ability is an aptitude that is grown up as the result of thought that acquired by the children in solving any cases that they face in the daily life. It can be seen through any activities in introducing mathematics such as classifying things by its color, shape, and size, making any patterns, sequence and size, numbers concept, one on one correspondence, comparation concept, geometry, estimation, currency, time, using any concrete media before abstract symbols, and creating interactions through playing.

The early mathematical ability is considered to be very important thing as a part of children development. [6] stated that mathematical ability becomes a current issue to be discussed especially among the parents.

The children's early mathematical ability can be seen from the children's aptitude in recognizing numbers, counting in a particular limit, even knowing simple addition and subtraction. Mathematics will be a long-life education on early childhood as a support in their life such thing as introducing them with currency, proportions, etc. Therefore, teachers are needed to give them any stimulus and measure whole aspects of their activities when they are learning. Oleh karena itu perlunya stimulasi yang tepat yang diberikan oleh guru, selain it. [7] added that the mathematical concept for early childhood is started by matching, classifying or placing several things in specific shapes or categories, comparing, and equalizing. Another theory argued that the mathematical concept is consisted of; a) matching and discriminating, comparing and contrasting, b) 
classifying, sorting and grouping, c) ordering, sequence and seriation [8]

In fact, the children's early mathematical abilities are less optimal because of teachers' major role in class and teachers' lack ability in stimulate the children properly. It is supported by [9] who stated that the Indonesian students' mathematical ability is far way down from the international standard. None of Indonesian students reach a proficient standard. In high level, they can only reach $2 \%$, while in middle level they only reach $15 \%$. Additionally, the Indonesian students who get low level of early mathematical abilities is $43 \%$ in total. This situation brings teachers to give an inappropriate assessment which is different with the fact. Teachers are overwhelmed with the numbers of report that is referred to Standar Pencapaian Perkembangan Anak (STPPA) as accordance with the existed assessment technique, such as observation, anecdote, portfolio, attainment, performance, assignment, and conversation. It will bring out cases related with the teachers' error in teaching.

According to the preliminary study that was conducted in TK Negeri Kintamani, there are several issues that is found in the learning process, especially in early mathematics, such as the less conception of numbers, counting, ordering, and lack capability in solving simple cases. Other issues which are found in B group of TK Negeri Kintamani is a homogenous way where the students are only rolled as the object of the learning process and the lack creativity of the teacher in using any classroom learning approaches. In addition, the general challenges which are faced by the teachers, specifically less activeness of the students and less accurate instrument of assessment that causes low learning achievement.

Therefore, the instrument that is used to assess the early mathematical abilities of B group students can be develop in order to reach an accurate and optimal assessment. Assessment is a systematic procedure which consisted of collecting, analyzing, and interpreting information in order to gain a conclusion about the characteristic of the measured object [10]. Added by Mulyasa [11] assessment is considered as a process of collecting, reporting, and making use the information about the students' learning result by applying the assessment principle, the continuous process, the authentic evidences, the accuracy, and the consistency.

This instrument of assessment is composed in accordance with theory that examine the learning process of the children's early mathematical ability in classroom. The development of the assessment instrument is carried out through expert judges and analysis of the result to obtain the validity and the reliability. In line with [12], the validity dan the reliability are the main requirement that must be fulfilled to gain an appropriate measurement tool. The validity is related with the instrument accuracy toward the measured object, while the reliability is related with the instrument worthiness as a measurement tool.

As aforementioned, the current study about the instrument used to assess the students' early mathematical ability in group B is conducted. In addition, the study is carried out entitled "The Appropriateness of The Instrument in Assessing Children's Early Mathematical Abilities of B Group at TK Negeri Kintamani in Academic Year 2019/2020”.

\section{METHOD}

The study is development research (Research and Development). The development is conducted toward the instrument of the early mathematical ability at B group in kindergarten. The RDR (Research, Development, Research) by Borg \& Gall [13] is used as the research model. The research subjects are B group students of TK Negeri Kintamani. The study is carried out along the even semester in academic year 2019/2020. Instrument of early mathematical ability is used as the dependent variable. This instrument is composed based on several indicators, such thing as: classifying, ordering or sequencing, corresponding one to one, comparing, and numbering.

The data is collected through questionnaire and interview. It is conducted in preliminary and development stages. In preliminary stage, the interview is carried out toward the teachers in B group. In product development stage, the interview and the questionnaire distribution are conducted toward the teachers to obtain their responds to the developed assessment instrument. The instrument used in the study is non-test instrument in form of questionnaire which consisted of negative and positive statements. There are 14 statements in total. The score of respondents' answers are given based on Likert scale. In a side, the positive statements detail will be: score 5 for "always", score 4 for "often", score 3 for "sometimes", score 2 for "rarely", and score 1 for "never". In another side, the negative statements detail will be: score 1 for "always", score 2 for "often", score 3 for "sometimes", score 4 for rarely", and score 5 for "never". The instrument test is conducted to obtain a result whether the instrument is appropriate to use or not The test that is used as the requirement of the instrument are validity and reliability test. Two experts are used to test the validity of the research instrument. 
Table 1. The Instrument Grid of Early Mathematical Ability

\begin{tabular}{|c|c|c|c|}
\hline Aspects & Dimension & Indicators & Items \\
\hline \multirow[t]{5}{*}{$\begin{array}{l}\text { Early Mathematical } \\
\text { Ability of Early } \\
\text { Childhood }\end{array}$} & Classifying & $\begin{array}{l}\text { 1. Classifying based on the colors } \\
\text { 2. } \quad \text { Classifying based on the shapes }\end{array}$ & $\begin{array}{l}1 \\
2 \\
3\end{array}$ \\
\hline & Matching & $\begin{array}{l}\text { 1. Matching things with the pairs } \\
\text { 2. Matching things based on the colors } \\
\text { 3. Matching things based on the shapes }\end{array}$ & $\begin{array}{l}4 \\
5 \\
6\end{array}$ \\
\hline & Ordering & $\begin{array}{ll}\text { 1. } & \text { Ordering things based on the size } \\
\text { 2. } & \text { Ordering things based on the length } \\
\text { 3. } & \text { Ordering things based on the height }\end{array}$ & $\begin{array}{l}7 \\
8 \\
9\end{array}$ \\
\hline & Comparing & $\begin{array}{ll}\text { 1. } & \text { Comparing things based on the size } \\
\text { 2. } & \text { Comparing things based on the length } \\
\text { 3. } & \text { Comparing things based on the height }\end{array}$ & $\begin{array}{c}10 \\
11 \\
12\end{array}$ \\
\hline & Counting & $\begin{array}{ll}1 & \text { Counting forward with things } 1-20 \\
2 & \text { Counting backward with things } 20-1\end{array}$ & $\begin{array}{l}13 \\
14\end{array}$ \\
\hline
\end{tabular}

\section{RESULTS AND DISCUSSIONS}

After the validity level of the expert judges result is completely analysed, the step is continued to analyse the reliability of the children's early mathematical ability instrument. The reliability test of the instrument is analysed using Microsoft Excel 2010. The recaputalion of experts score toward every item of the instrument could be illustrated as following Table 2 .

Table 2. The Recapitulation of Experts Score Toward the Instrument Items

\begin{tabular}{|c|c|c|c|c|c|c|}
\hline \multirow{2}{*}{ Number of the Items } & \multicolumn{2}{|c|}{ Experts } & \multirow{2}{*}{ Scores } & \multirow{2}{*}{$\boldsymbol{P}$} & \multirow{2}{*}{$q$} & \multirow{2}{*}{$p q$} \\
\hline & 01 & 02 & & & & \\
\hline 1 & 1 & 1 & 2 & 1 & 0 & 0 \\
\hline 2 & 1 & 1 & 2 & 1 & 0 & 0 \\
\hline 3 & 1 & 1 & 2 & 1 & 0 & 0 \\
\hline 4 & 1 & 1 & 2 & 1 & 0 & 0 \\
\hline 5 & 1 & 0 & 1 & 0.5 & 0.5 & 0.25 \\
\hline 6 & 1 & 1 & 2 & 1 & 0 & 0 \\
\hline 7 & 1 & 1 & 2 & 1 & 0 & 0 \\
\hline 8 & 1 & 1 & 2 & 1 & 0 & 0 \\
\hline 90 & 1 & 1 & 2 & 1 & 0 & 0 \\
\hline 10 & 1 & 0 & 1 & 0.5 & 0.5 & 0.25 \\
\hline 11 & 1 & 1 & 2 & 1 & 0 & 0 \\
\hline 12 & 1 & 1 & 2 & 1 & 0 & 0 \\
\hline 13 & 1 & 1 & 2 & 1 & 0 & 0 \\
\hline 14 & 1 & 1 & 2 & 1 & 0 & 0 \\
\hline$\sum p q$ & \multicolumn{3}{|c|}{0,5} & & & \\
\hline $\mathrm{N}$ & \multicolumn{3}{|c|}{14} & & & \\
\hline St2 & \multicolumn{3}{|c|}{2} & & & \\
\hline $\mathrm{r} 11$ & \multicolumn{3}{|c|}{0,80} & & & \\
\hline
\end{tabular}

As illustrated in Table 02, the coeficiency of the instrument reliability is 0,80 which means that the instrument is categorized in very high criteria of the reliability.
The development of the children's mathematical abilities of B group at TK Negeri Kintamani in academic year 2019/2020 is conducted using RDR model through several phases specifically research, development, and research. The RDR model is used because of the 
simplicity, systematicity, and clearness of the phases [14].

The first phase is research which conducted through preliminary study in analyzing the instrument related with the needs, conditions, and curriculum in purpose to gain data that use to design the assessment instrument based on problems found. The need analysis through preliminary study is a starting step in conducting research with RDR model [15]. Based on the interview that conducted with the teachers and the learning process observation in class, it is revealed that the instrument that used to asses the students' early mathematical ability is simple and less accurate. Therefore, from the analysis result, the instrument that use in assessing the students' early mathematical ability of B group at TK Negeri Kintamani in academic year 2019/2020 can be arranged.

The second phase is development. It is conducted based on analysis result of the preliminary study. The result of the need analysis is used to decide the next phase, that is the arrangement and the production of the product [15]. The development is conducted by determining a product in instrument form of the early mathematical ability especially composing the assessment grid. The aspects of early mathematical ability in the grid are developed to be more specific through designing the assessment indicators.

The research is the last phase that conducted after arranging the instrument in the learning process. The product test aims to gain affectivity, efficiency, and benefits from the developed product [16]. After finished the instrument design, two experts will give their judges toward the appropriateness of the product using scoring sheets that consisted of two answers, specifically relevant and irrelevant. The product validity result is continued by revising the product. The revision is related with the comments and suggestions that are given by the experts.

The data that is given by the two experts is analyzed in order to know the level of validity and reliability of the developed instruments. [17] stated that instrument is a tool that used to measure the evaluation of the learning activity. From the expert judges, it is revealed that 12 from 14 instrument items are categorized as relevant and the rest items are categorized irrelevant. The relevant numbers are $1,2,3,4,6,7,8,9,11,12,13,14$, meanwhile the irrelevant numbers are 5 and 10.

The analysis result of the instrument validity toward the assessment of early mathematical ability in the learning process is 0,75 and categorized as high validity level. In addition, the analysis result of the instrument reliability is 0,80 which categorized it in very high level of reliability.

The similar study shows a positive result as conducted by [18]. The data analysis result concludes that the instrument use to assess children's (5-6) language development is appropriate to use in obtaining data about the children's language development. Additionally, the quality is completely tested specifically in validity, reliability, and practical sides. It proves that the instrument is able to use by kindergarten teachers as a guidance to assess the children's language development. [19] added that test which conducted to 95 teachers from 15 different kindergarten in Malang in purpose of gaining a product practical data shows that 39 items are valid with total score 1979 in $87 \%$ of total percentage. This result indicates that the children's gross motor skill instrument is really practice to be used.

Based on the result analysis and the study result, it can be concluded that the instrument use in assessing the students' early mathematical ability of B group at TK Negeri Kintamani in academic year 2019/2020 is appropriate to use because of the high-level score of validity and reliability. This instrument is composed based on theories of early mathematical ability in order to make straight forward and accurate assessment according to the children's growth and development as well as the pointed purpose. The use of appropriate instrument will be able to give an accurate assessment to reach a maximum learning achievement.

\section{CONCLUSION}

Based on the research finding and discussion, it can be concluded that the instrument which use to assess the students' early mathematical ability of B group at TK Negeri Kintamani in academic year 2019/2020 is appropriate to use with the high level of validity and reliability. The data analysis shows that: the coefficient of the instrument reliability of the early mathematical ability is 0,80 and categorized as high level of reliability.

Suggestions for teachers are; giving more chances to students to be active in class and using the instrument that already fulfilled the requirement as an appropriate assessment tool. For the headmaster, it is suggested to give more facilities to the teachers to support their efforts in increasing the skills in managing the learning process, especially in developing the instrument or evaluation tool.

It will support the teachers in evaluating the students' ability in the learning process especially in early mathematical ability as accurate as it can to reach the maximum quality of learning process.

\section{ACKNOWLEDGMENT}

This work was supported by Universitas Pendidikan Ganesha (Undiksha) Singaraja, Fakultas Pendidikan Undiksha, and Program Studi PG PAUD FIP Undiksha.

\section{REFERENCES}

[1] C. N. Aulina, Pengaruh permainan dan penguasaan kosakata terhadap kemampuan membaca permulaan 
anak usia 5-6 tahun, PEDAGOGIA: Jurnal Pendidikan 1(2) (2012) 131-144.

[2] L. Purwanti, S. Widayati, Meningkatkan Kemampuan Pengenalan Huruf Hija'iyah (ض, ض (ظ, Dan Pada Anak Tk A Melalui Permainan Kartu Huruf, PAUD Teratai, vol. 5(3), 2016.

[3] Y. N. Sujiono, Metode Pengembangan Kognitif, Jakarta: Universitas Negeri Terbuka, 2008.

[4] A. Astuti, L. Leonard, Peran Kemampuan Komunikasi Matematika Terhadap Prestasi Belajar Matematika Siswa, Formatif: Jurnal Ilmiah Pendidikan MIPA, vol. 2(2), 2015.

[5] Z. Arifin, Evaluasi Pembelajaran, Bandung: PT Remaja Rosdakarya, 2009.

[6] S. Utoyo, I. N Arifin, Model Permainan Kinestetik untuk Meningkatkan Kemampuan Matematika Awal pada Anak Usia Dini, Jurnal Pendidikan Usia Dini 11(2) (2017) 323-332.

[7] N. Nurhazizah, Peningkatan Kemampuan Matematika Awal Melalui Strategi Pembelajaran Kinestetik, Jurnal Pendidikan Usia Dini, 8(2) (2014) 337-346.

[8] T. Johnson, Kennedy, Guiding Children's Learning of Mathematics, New York: Wadsworth Cengage Learning, 2011.

[9] R. Ningsih, A. Nurrahmah, Pengaruh Kemandirian Belajar dan Perhatian Orang Tua terhadap Prestasi Belajar Matematika, Formatif: Jurnal Ilmiah Pendidikan MIPA, vol. 6(1), 2016.

[10] V. Iswantiningtyas, W. Wulansari. Pengembangan Model Penilaian Pendidikan Karakter Anak Usia Dini, Jurnal Pendididkan Usia Dini, 2018.

[11] I. F. Zahro, Penilaian dalam pembelajaran anak usia dini, Tunas Siliwangi: Jurnal Program Studi Pendidikan Guru PAUD STKIP Siliwangi Bandung 1(1) (2015) 92-111.

[12] S. Alam, M. Japar, M. N. A. Asnur, Pengembangan Instrumen Tes Siswa Tingkat Sekolah Dasar di Kabupaten Kuningan, Qalam: Jurnal Ilmu Kependidikan 8(1) (2019)59-68.

[13] B. Biliandri,, S. Supriyono, A. Pujianto, B. Priyono, Pengembangan Konservatif Games In Aquatic Untuk Meningkatkan Kebugaran Jasmani Dan Sportivitas Siswa Sekolah Dasar, Jp. jok (Jurnal [7] Pendidikan Jasmani, Olahraga dan Kesehatan) 2(1) (2018) 70-79.

[14] K. N. A Sudarsana, P. A. Antara, I. K.. Dibia, Kelayakan Instrumen Penilaian Keaktifan Belajar PPKn. Mimbar PGSD Undiksha 8(2) (2020) 150158.
[15] S. Nurmasitah, U. Achmad, W. Prasetyaningtyas, F. Fatati, Pengembangan Model Pembelajaran Penyusunan Proposal Penelitian untuk Meningkatkan Keterampilan Penulisan Karya Ilmiah Mahasiswa, TEKNOBUGA: Jurnal Teknologi Busana dan Boga 5(2) (2017) 66-73.

[16] Yurnalis. Upaya Meningkatkan Kemampuan Guru dalam Menyusun Perangkat Pembelajaran Melalui Supervisi Klinis di Sekolah Binaan Kecamatan Cerenti, Jurnal Pendidikan dan Pengajaran Universitas Riau, Volume 2, 2018.

[17] S. Alam, et. al., Pengembangan Instrumen Tes Siswa Tingkat Sekolah Dasar Kabupaten Kuningan, Jurnal Ilmu Kependidikan, Volume 8, No. 1, 2019.

[18] S. N. Aini, Pengembangan instrumen asesmen perkembangan bahasa anak usia 4-5 tahun, Pengembangan instrumen asesmen perkembangan bahasa anak usia 4-5 tahun/Siti Nur Aini, 2016.

[19] E. P. M. Sari, Pengembangan instrumen asesmen motorik kasar anak usia 5-6 tahun di Taman KanakKanak, 2016. 